\title{
Agro-ecological Lower Midland Zones IV and V in Kenya Using GIS and Remote Sensing for Climate-Smart Crop Management
}

\author{
Hilda Manzi and Joseph P. Gweyi-Onyango
}

\section{Contents}

Introduction ........................................................... 966

Climate Change and Its Impacts in Lower Midland Agro-ecological

Zones IV and V .................................................... 966

Climate Variability in Agro-ecological Lower Midland Zones IV and V Soil, Air, and Land

Surface Temperature Variations ............................................ 972

Precipitation Amount, Rate, and Soil Moisture Variations .......................... 978

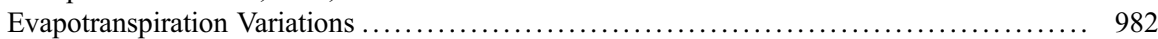

Contribution of GIS and Remote Sensing in Agro-ecological Zone Evaluations ............ 984

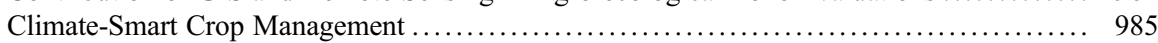

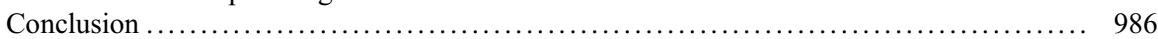

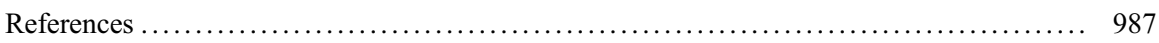

\section{Abstract}

Food production in Kenya and Africa in recent past has experienced vagaries of weather fluctuations which ultimately have affected crop yield. Farming in Kenya is localized in specific Agro-ecological zones, hence understanding crop growth responses in particular regions is crucial in planning and management for purposes of accelerating adoption. A number of strategies for adoption and adaptation to changing weather patterns have been deployed yet only limited challenges have been partially addressed or managed. This chapter examines previous methods used in classifying agro-ecological zones and further provides additional insightful parameters that can be adopted to enable farmers understand and adapt better to the current

This chapter was previously published non-open access with exclusive rights reserved by the Publisher. It has been changed retrospectively to open access under a CC BY 4.0 license and the copyright holder is "The Author(s)". For further details, please see the license information at the end of the chapter.

H. Manzi $(\bowtie) \cdot$ J. P. Gweyi-Onyango

Department of Agricultural Science and Technology, Kenyatta University, Nairobi, Kenya

e-mail: gweyi.joseph@ku.ac.ke 
variable and unpredictable cropping seasons. The chapter scrutinizes past and current documented information on agro-ecological zonal valuations coupled with the use of earth observation components such as air temperature at surface, land surface temperature, evapotranspiration, soil, temperature, and soil and moisture content in order to better understand and effectively respond to new phenomena occurring as a result of climate change in the marginal agricultural areas. Significant variations in precipitation, ambient temperature, soil moisture content, and soil temperature become evident when earth observation data are used in evaluation of agroecological lower midland zones IV and V. The said variations cut across areas within the agro-ecological zones that have been allocated similar characteristics when assigning cropping seasons. The chapter summarizes the outcomes of various streams of contributions that have reported significant shifts or changes in rainfall and temperature patterns across Kenya and wider Eastern Africa region. The chapter highlights the need for re-evaluation of the agro-ecological zones based on the recent earth observation datasets in their diversity. The research emphasizes the use of multiple climate and soil-related parameters in understanding climate change in the other marginal areas of Kenya.

\section{Keywords}

Climate change $\cdot$ Length of growth period $\cdot$ Cropping seasons $\cdot$ Earth observation data

\section{Introduction}

\section{Climate Change and Its Impacts in Lower Midland Agro-ecological Zones IV and V}

The worrying trends and implication of the changing climatic patterns and extreme weather events have been previously documented (Donat et al. 2013; Schneider et al. 2018). One of the major concerns is the shift in weather patterns and its adverse effect on rain-fed agriculture. Previous work (Pearce 2000; Rosenzwerg, and le Parry 1994) have shown the vulnerability of most developing countries to climate change. Seo et al. (2009) evaluated the effects of climate variability in Africa and singled out the semi-arid areas as the most sensitive while the productive areas such as the high to medium wet zones becoming even more useful for agriculture. These researchers highlight the role that agro-ecological zones play to bring out the understanding of climate change and further emphasize the role of climate change on the impact on crops and livestock in light of changing economic value. They further observed that climate resilience is built more on net crop and livestock revenue combined rather than crop or livestock alone, particularly the African region. Mendelsohn (2008) links markets and places the largest economic impact of climate change upon agriculture. Furthermore, studies in developing countries have pointed to challenges in placing the economic value to agriculture due to lack of data on farm performance, 
as argued by Mendelsohn (2008). The author draws parallels from tropical and subtropical agriculture and is of the opinion that both regions are more sensitive to climate change compare to temperate zones and that the level of effect emanate more on climate scenarios at hand than agriculture practices or level of farming activities. In addition, the climate variability differs from one country to another and differences are also evident within regions in the countries (Mendelsohn 2008).

Kenya has experienced extreme rainfall events in every 3 years cycle on average based on the 1989-2011 analysis (Ndirangu et al. 2017). In the same period, severe droughts and changes in rainfall variability have become inevitable. These have severely affected farmers who depend on rain-fed agriculture and have eventually become victims of climate variability and extreme weather events. Furthermore, the global financial and economic crisis have made the situation worse through the disruption of agricultural supply chains and market, weakening the ability of the agricultural sector to address food security. Despite intervention in agriculture, crop, and livestock production system are still sensitive to drought and other extreme weather events especially in arid and semi-arid areas as indicated by Ndirangu et al. (2017). This confirms the existence of fragile local mechanism for coping and poor resilience to cushion against future climate change shocks. Ochieng (2015) discusses the impact of climate change on agricultural production and considers rainfall and temperature has having positive effects on the revenues of most crops. Fluctuation of temperature and rainfall in growing seasons is known to cause serious problems in normal plant processes, hence crop losses are inevitable. The findings by Ochieng (2015) stressed the significance of the longstanding effects of climate change in terms of temperature changes to have an adverse effect on crop production compared to interim effects. The impacts of temperature in this respect significantly override those of rainfall fluctuations. Fischer (2006) predicted that the global warming phenomenon would lead to higher temperatures and modify precipitation levels which to far extent have had an impact on the productivity of land suitable for agriculture. These are some of the current events being experienced in countries such as Kenya. He further concluded that the integration of agro-ecological zonal methodologies and socioeconomic models could provide right tools for land use planning and resource development.

Farming in most parts of Africa, Kenya included, revolves around agroecological zones. It is the agro-ecological zones as defined by FAO (1978) and improved by Jiitzold and Kutsch (2000) through the farm management guidelines that determine where crops can be suitably grown. In this agro-ecological zones, cropping seasons have been identified based on the length of growing periods. In addition, FAO (1978) defines agro-ecological zoning (AEZ) as the use of soil parameters, natural features, and climate characteristics to demarcate areas potential for agricultural production. The particular parameters used in the agro-ecological zoning and cropping pattern assign more focus on the climatic and soil, chemical, and physical parameters and their requirements by crops and on the management systems under which the crops are grown. Each zone has a similar definition to ensure its suitability to support certain functions. This kind of evaluation calls for certain recommendations designed to improve the existing land-use suitability situation, either through increasing advocacy for production or by barring use due 
to land degradation. Moreover, the studies on agro-ecological zoning put emphasis on the use of FAO classification of 1978 which looks at the ability of agricultural land to support crop production through length of growing period, temperature, and precipitation. According to FAO (1978), this length of growing period is understood to be the period where rainfall and stored soil moisture is greater than half of the evapotranspiration. This, therefore, simply means the longer the growing season, the more the plants to be planted, the longer the period for plant carbon fixation, and the higher the yields. Vrieling et al. (2013) indicate that the length of growing period is analyzed based on weather station data, which are unfortunately quite scarce in Africa or depend coarse rainfall satellite data that are not reliable. The findings reported by Vrieling et al. (2013) clearly show that there are high variability in length of growth period in arid and semi-arid areas. This is further confirmed by the high crop failure rate in the same regions.

Length of growth periods derived from earth observation data such as GIMMS Normalized Difference Vegetation Index generation 3 (NDVI3g) dataset provided useful information for mapping of farming system as well as study of climate variability. The other option for assessing the length of growing periods is documented elsewhere (De Beurs and Henebry 2010; White et al. 2009) and consider use of time-series remote sensing data. The remote sensing methods have been found to be convenient in providing useful information for understanding cropping patterns especially at the start and end of seasons. If such information is properly harnessed can provide early warning systems that can be leveraged on for efficient planning. Henricksen (1986) discussed the need for proper definition of agro-ecological zones in Africa. According to him, it would enhance the ease in collecting and updating agro-ecological data and further give a better latitude for proper definition of the cropping seasons.

The role of agro-ecological zone in defining the crop environment in Kenya, has been generated from the agro-climatic zones. An agro-ecological zone is therefore defined by its relevant agro-climatic factors, especially the moisture supply and differentiated as well by soil patterns. The aim is to provide a frame-work for the natural land use potential. The main zones are therefore differentiated by their ability to provide temperature and water requirements for the specific crops in that particular agro-ecological zone. This is related to the climatic yield potentials as calculated from the computer. Once these zones are established, they are comparatively run alongside the Braun's climatic zones of the precipitation/evaporation index as shown by Le Page et al. (2017). The comparability is expected to have variances due to the influence of the length and intensity of arid periods, a factor that has also to be considered. New agro-ecological zoning methodologies have been done and found to be effective in assessing crops against climate vulnerability (Le Page et al. 2017).

Climatic changes have caused drastic weather patterns over the years where more consideration other than length of the growing period are needed. The current length of growing periods are characterized by intensive precipitation whose distribution is poor while at the same time high temperatures are experienced in-between period of precipitation cessation. Inclusion of earth observation data, therefore, becomes very critical in understanding developing climate variability within the existing 
agro-ecological zones and thereafter necessitating technologies that can accommodate significant changes. Earth observation data and remote sensing technologies have improved and hence provide near real-time observations. Moreover, the placement of rain gauges which determine the precipitation data is sparse and may not reflect microclimatic changes that have occurred over the years as argued by Vrieling et al. (2013). The evaluation of agro-ecological zone focuses on changes in precipitation, temperatures, and soil characteristics which have necessitated the interpretation of changes in growing periods over the years using earth observation data. Furthermore, there has been a pressing need to adapt climate-smart crops for the various regions in Kenya. Coincidentally, climate-smart crop management in the twenty-first century is the new paradigm shift that may be panacea to majority of rain-fed smallholder farmers to cope with climate change. This chapter therefore calls for use of earth observation data such as soil surface moisture data, varied temperature parameters, varied precipitation parameters, and other relevant parameters that can enable the evaluation of cropping seasons based on gridded variation found within the agro-ecological zones from earth observation datasets.

Previous studies have shown that rainfall levels are bound to decrease, increase, or remain the same under most climate scenarios albeit with a lot of extremes in some scenarios, while the temperature are likely to increase. It is these impacts and implications of such reports that have necessitated the need to reevaluate the agroecological zonation and infer whether there any significant changes in the growing periods. Ayugi and Tan (2019) revealed a rise in temperature which might contribute to hydrological droughts in the arid and semi-arid areas in future. Additional information have pointed out the need to analyze for specific trends and thereafter characterize areas in terms of vulnerability to climate, particularly the semi-arid areas of Africa, Kenya included. King'uyu et al. (2000) noted significant changes over the surface temperature based on data collected in 71 stations for the period 1939-1992 in Eastern Africa. Unfortunately, geographical variability in nighttime temperature was difficult to interpret thereby calling for further research. Nsubuga and Rautenbach (2018) did a review of climate change and variability in Uganda and confirmed a growing trend in changes in temperature and rainfall and, moreso, in the Eastern Africa region where Kenya and Uganda lie. Hastenrath (2001) and Schreck and Semazzi (2004) have also done extensive work on climate change in East Africa and significantly provided information on changes in weather patterns over years. These reviews of scientific research findings have created a better understanding of the recent climate changes and variabilities in Kenya and provide further information for use in future research and adaptive actions.

The use of earth observation data in climate change monitoring cannot be overemphasized. Earth observation data have provided important insights into important parameters such as biological, physical, and chemical in its bid to address climate change needs and adaptation strategies (Guo et al. 2015). The capacity of earth observation data is advanced in terms of temporal and spatial scales. The complexity in the study of climate change in the aspects of atmosphere, oceans, and lands, make earth observation data an important option as stressed by Guo et al. (2015). The launch of various datasets by NASA and their availability to near real 
time open a huge platform for addressing climate change issues in Africa. The current chapter attempts to integrate a number of these options to give insights to climate-smart agricultural option in these fragile agro ecological zones IV and V with an aim of providing strong adaptation and adoption strategies to variable weather and cropping seasons.

This chapter focuses on the agro-ecological zones IV and V of the marginal lands of Tharaka-Nithi, Meru, Makueni, and Machakos counties that run along a similar agro-climatic belt in Eastern Kenya. These areas cover semi-arid region where most farmers depend on rain-fed agriculture for livelihood. These areas are characterized by crops as such green grams, sorghum, millet, and pigeon peas. Agro-ecological zones IV and V are classified as a Lower Midlands that are found in semi-arid areas (FAO 1996). According to FAO (1978), the various cropping patterns in the two rainy seasons are evaluated as having the following characteristics:- very short to short and very short cropping seasons, very short to short and very short to short cropping seasons, very short to very short to short cropping seasons, two very short cropping seasons, very uncertain and very short to short cropping season, and finally very uncertain and very short cropping season for Tharaka Nithi. Part of Meru that form part of the agro-climatic belt of Tharaka-Nithi have similar cropping pattern. Machakos' lower midlands zone $\mathrm{V}$ is also characterized by very short and very short to short cropping seasons, very short and very short cropping seasons, and finally very short to short and very short to short cropping seasons. Kitui, on the other hand, has very short to short and short to very short cropping seasons, very short and very short cropping seasons, very uncertain and short to short cropping seasons for both zones IV and V (Jiitzold and Kutsch 2000). The average rainfall and temperatures for Tharaka Nithi, Meru, Makueni, Kitui, and Machakos lower midland zones IV and V as documented by the farm management hand book of Kenya is illustrated in Table 1. Illustration of the these zones are also shown in Fig. 1.

\section{Earth Observation Products in Climate Change Monitoring}

Time average, soil moisture content underground, land surface skin temperature, multiyear monthly mean surface temperature, air temperature, total precipitation flux, total surface precipitation flux, total surface precipitation, precipitation rate, combined gauge precipitation, monthly precipitation, climatology rainfall flux, and monthly evapotranspiration for varied periods products were obtained from earth observation Geospatial Interactive Online Visualization and Analysis Infrastructure (GIOVANNI) NASA web portal. The products used were precipitation rates in $\mathrm{mm}$ /day with a spatial resolution of $0.25^{\circ}$ for the period 1998-2019. Precipitation rates here refers to rainfall intensity. Another product used was amount of precipitation on monthly basis recorded as mm/day for the period 1998-2017 packaged as time average maps at $0.5^{\circ}$ spatial resolution. Thirdly, soil moisture content underground at $0-10 \mathrm{~cm}, 10-40 \mathrm{~cm}$, and $40-100 \mathrm{~cm}$ was also evaluated. The products were obtained from NOAH through the GLDAS model for the period 2000-2019. Alongside these, the soil temperature at $0-10 \mathrm{~cm}, 10-40 \mathrm{~cm}$, and $40-100 \mathrm{~cm}$ was obtained from Atmospheric Infrared Sounder (AIRS)/National Oceanic and Atmospheric Administration (NOAA) products for the period 1998-2014 at $0.25^{\circ}$ spatial 
resolution. Another temperature parameter examined was the products of air temperature at surface day time and night time as obtained from AIRS/STM for the period 2002-2016 at $1^{\circ}$ spatial resolution. Further products on evapotranspiration from NLDAS/MOSO for the period 1998-2014 at $0.25^{\circ}$ spatial resolution. The dataset used for this study are general time average maps for periods not less than 10 years to bring various phenomena of variation in the area of study. These phenomena are meant to provide current insight into climate change variability and influence in agro-ecological lower midland zones IV and V. The remote sensing product analyses were done using QGIS, Terrset software, and other GIS software. This was to get current status of the agro-ecological lower midland zones IV and V and whether there are any indications that can lead to change in cropping season and suitability of crops. Other products examined include time average products on amount and distribution of the precipitation as compared to studies done by Jiitzold

Table 1 Characterization of lower midland zone V based on cropping season, annual temperature, and annual average rainfall - Jatzold and Kutsch 2000)

\begin{tabular}{|c|c|c|c|c|}
\hline $\begin{array}{l}\text { Name of the } \\
\text { county }\end{array}$ & $\begin{array}{l}\text { Agro-ecological } \\
\text { zones IV and V }\end{array}$ & $\begin{array}{l}\text { Cropping season in } \\
\text { the two rainy seasons }\end{array}$ & $\begin{array}{l}\text { Annual mean } \\
\text { temperature in } \\
{ }^{\circ} \mathrm{c}\end{array}$ & $\begin{array}{l}\text { Annual average } \\
\text { rainfall in } \mathrm{mm}\end{array}$ \\
\hline \multirow[t]{7}{*}{$\begin{array}{l}\text { Tharaka } \\
\text { Nithi and } \\
\text { Meru }\end{array}$} & \multirow[t]{6}{*}{$\mathrm{V}$} & $\begin{array}{l}\text { Very short to short } \\
\text { and very short to } \\
\text { short }\end{array}$ & \multirow[t]{6}{*}{$24-22.9$} & $800-900$ \\
\hline & & $\begin{array}{l}\text { Very short to short } \\
\text { and very short }\end{array}$ & & Too small \\
\hline & & $\begin{array}{l}\text { Very short and very } \\
\text { short to short }\end{array}$ & & $750-870$ \\
\hline & & $\begin{array}{l}\text { Very short and very } \\
\text { short }\end{array}$ & & $650-850$ \\
\hline & & $\begin{array}{l}\text { Very uncertain and } \\
\text { very short to short }\end{array}$ & & $630-660$ \\
\hline & & $\begin{array}{l}\text { Very uncertain to very } \\
\text { short }\end{array}$ & & $600-700$ \\
\hline & IV & $\begin{array}{l}\text { Short to very short } \\
\text { and short to very } \\
\text { short }\end{array}$ & $23.5-21.0$ & $820-920$ \\
\hline \multirow[t]{5}{*}{$\begin{array}{l}\text { Machakos } \\
\text { and } \\
\text { Makueni }\end{array}$} & \multirow[t]{5}{*}{ V } & $\begin{array}{l}\text { Very short to short } \\
\text { and very short to } \\
\text { short }\end{array}$ & \multirow[t]{5}{*}{$24-21.6$} & $650-750$ \\
\hline & & $\begin{array}{l}\text { Very short and very } \\
\text { short to short }\end{array}$ & & $600-800$ \\
\hline & & $\begin{array}{l}\text { Very uncertain and } \\
\text { very short to short }\end{array}$ & & $600-700$ \\
\hline & & $\begin{array}{l}\text { Very uncertain to very } \\
\text { short }\end{array}$ & & $690-700$ \\
\hline & & $\begin{array}{l}\text { Very short and very } \\
\text { short }\end{array}$ & & No data \\
\hline
\end{tabular}


Table 1 (continued)

\begin{tabular}{|c|c|c|c|c|}
\hline $\begin{array}{l}\text { Name of the } \\
\text { county }\end{array}$ & $\begin{array}{l}\text { Agro-ecological } \\
\text { zones IV and V }\end{array}$ & $\begin{array}{l}\text { Cropping season in } \\
\text { the two rainy seasons }\end{array}$ & $\begin{array}{l}\text { Annual mean } \\
\text { temperature in } \\
{ }^{\circ} \mathrm{c}\end{array}$ & $\begin{array}{l}\text { Annual average } \\
\text { rainfall in } \mathrm{mm}\end{array}$ \\
\hline & IV & $\begin{array}{l}\text { Short to very short } \\
\text { and short to very } \\
\text { short }\end{array}$ & $22.0-21.0$ & $700-850$ \\
\hline & & $\begin{array}{l}\text { Very short to short } \\
\text { and short to very } \\
\text { short }\end{array}$ & & $700-800$ \\
\hline \multirow[t]{9}{*}{ Kitui } & \multirow[t]{5}{*}{ V } & $\begin{array}{l}\text { Very short and very } \\
\text { short to short }\end{array}$ & \multirow[t]{5}{*}{$24.0-23.0$} & $650-790$ \\
\hline & & $\begin{array}{l}\text { Very short and very } \\
\text { short }\end{array}$ & & $600-780$ \\
\hline & & $\begin{array}{l}\text { Very uncertain and } \\
\text { very short to short }\end{array}$ & & $600-750$ \\
\hline & & $\begin{array}{l}\text { (Very short) and very } \\
\text { short }\end{array}$ & & $600-650$ \\
\hline & & $\begin{array}{l}\text { Very uncertain and } \\
\text { very short }\end{array}$ & & $550-630$ \\
\hline & \multirow[t]{4}{*}{ IV } & $\begin{array}{l}\text { Short to very short } \\
\text { and short }\end{array}$ & \multirow[t]{4}{*}{$24.0-20.9$} & $800-1000$ \\
\hline & & $\begin{array}{l}\text { Very short to short } \\
\text { and short to very } \\
\text { short }\end{array}$ & & $750-880$ \\
\hline & & $\begin{array}{l}\text { Very short and short } \\
\text { to very short }\end{array}$ & & $700-820$ \\
\hline & & $\begin{array}{l}\text { Very uncertain and } \\
\text { short to very short }\end{array}$ & & $720-820$ \\
\hline
\end{tabular}

and Kutsch (2000) that are mostly used for national policy planning on cropping season in Kenya through the farm management guideline books.

\section{Climate Variability in Agro-ecological Lower Midland Zones IV and V Soil, Air, and Land Surface Temperature Variations}

This chapter gives a brief overview of air temperatures, land surface temperature, and multiyear land surface skin temperature daytime for the period 2000 to 2016 that depict an upward trend in temperature changes (Figs. 2 and 3, respectively) for zones IV and V. These areas that include parts of Makueni and Kitui show temperatures of between $26{ }^{\circ} \mathrm{C}$ and $31^{\circ} \mathrm{C}$ while Machakos, Tharaka, and parts of Meru have temperature ranges of $24-26^{\circ} \mathrm{C}$. These temperatures changes compared closely with those earlier reported by Jiitzold and Kutsch (2000) (Table 1) with annual average temperature ranges of $22-24{ }^{\circ} \mathrm{C}$ for Machakos, Kitui, and Makueni indicating an increasing trend in temperature. Tharaka Nithi and parts of Meru temperature fluctuate between $24-26{ }^{\circ} \mathrm{C}$ and $22-24{ }^{\circ} \mathrm{C}$, respectively. The trend of temperature 
Fig. 1 Agro-ecological lower midland zone IV and $\mathrm{V}$ in Machakos, Kitui and Tharaka Nithi
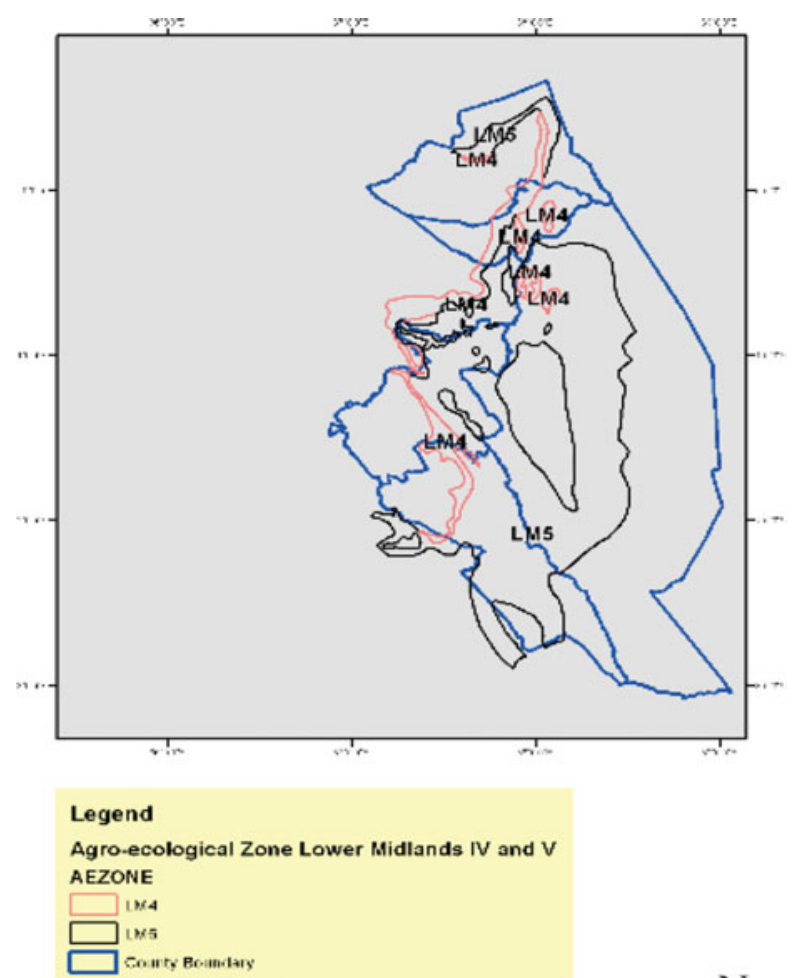

Agro-ecological Lower Midland zone IV and V in Machakos,Kitui and Tharaka Nithi

variations confirms reports by previous studies (Nsubuga et al. 2014; Omondi et al. 2014), an indication of increase in temperature trends and variability over East Africa. The challenge of variations from one locality to another as highlighted by Omondi et al. (2014) may be solved through having gridded earth observations data. Earth observation data provide spatial resolution smaller compared to data collected from various in situ stations whose spatial resolutions are usually very wide due to unavailability of adequate and well-distributed weather or radar station in Kenya. There are pockets of temperature variations as shown on the time-average maps of air temperature for the period 2002-2016 which is a 14-years-period for both daytime and nighttime (Fig. 2). This is an indication that over the years, different areas within the agro-ecological zones of lower midland IV and V have experienced climate variability in terms of temperature changes. This may also imply that the length of growing periods of crops are different within the same zone. Vrieling et al. (2013) is of the opinion that the distribution of crop and farming systems go hand in hand with the length of growing period. They further note that length of growing period in Africa (Kenya included), have been determined by weather station data with poor spatial distribution. 
Climate change over the years has been studied and confirmed to cause a fluctuation in the length of growing periods as shown by Gregory et al. (2005). Moreover, Ayugi and Tan (2019) brings out the importance of surface air temperature as one of the parameters to be considered and blends well with the current finding in regard to agro-ecological lower midland zone IV. Ayugi and Tan (2019) further highlights the significant role of this type of products in the assessment of climate change variability for interpretation of the overall climate state in Kenya. His observations depict a trend of increasing temperatures in the period between 1971 and 2010. Similar inferences are drawn from the earth observation climate products for air temperature at surface for the period 2002 to 2016 in the similar areas. The air temperature at surface (Fig. 2) varies significantly within the agro-ecologies of lower midland zones IV and V. These datasets if generally compared to data by Jiitzold and Kutsch (2000) in Table 1 are possible to infer that there is an increasing trend in temperature. Rise in temperatures were predicted to increase between $1{ }^{\circ} \mathrm{C}$ and $2.5^{\circ}$ $\mathrm{C}$ on average, with a predictive temperature change in 2020 being between $1^{\circ} \mathrm{C}$ and $2{ }^{\circ} \mathrm{C}$ for 2030 and $2.5^{\circ} \mathrm{C}$ for 2040 (Eitzinger et al. 2011). These predictions are likely to change crop suitability for various regions as further argued by Eitzinger et al. (2011) based on research that displays maps with changing suitability of tea growing area in Kenya. He further cautions that areas between 1400 and 2000 meters above
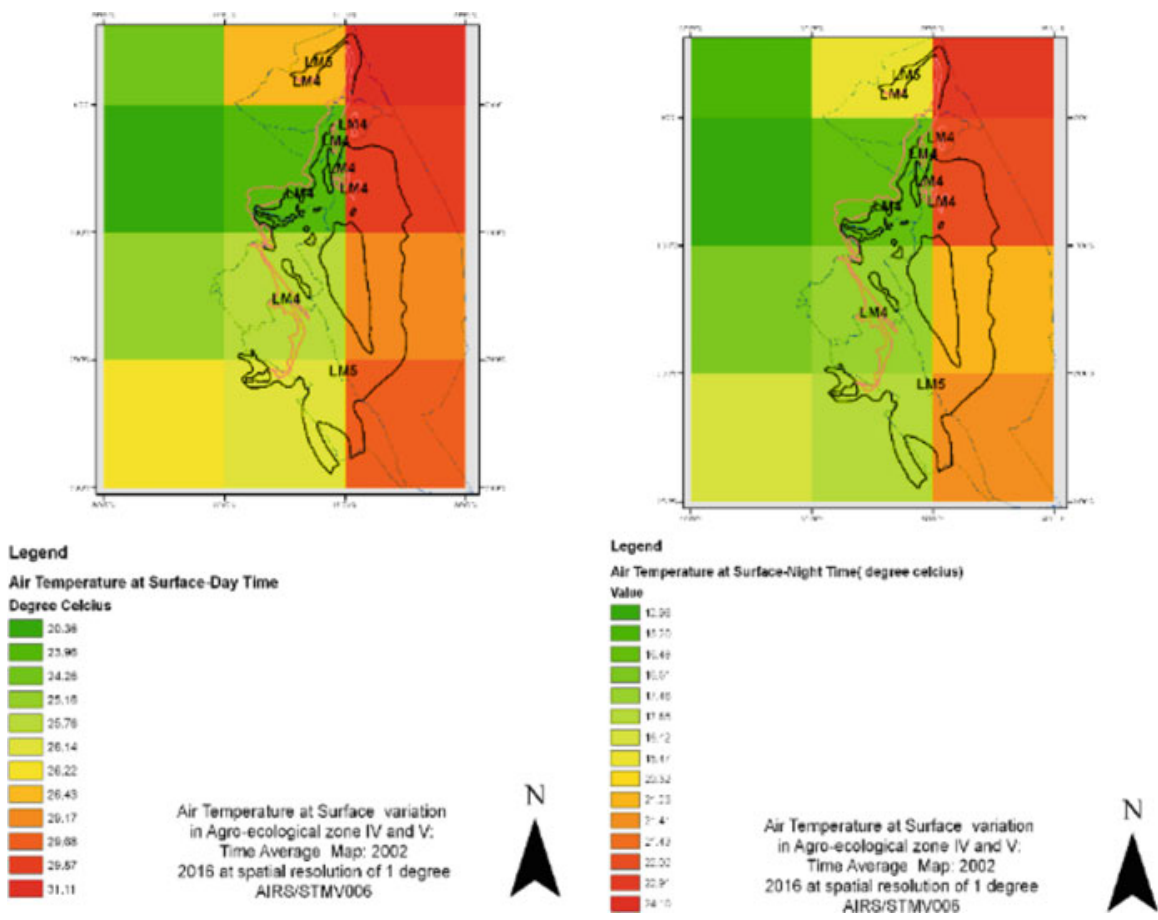

Fig. 2 Air temperature at surface variation in agro-ecological lower midland zone IV and V 

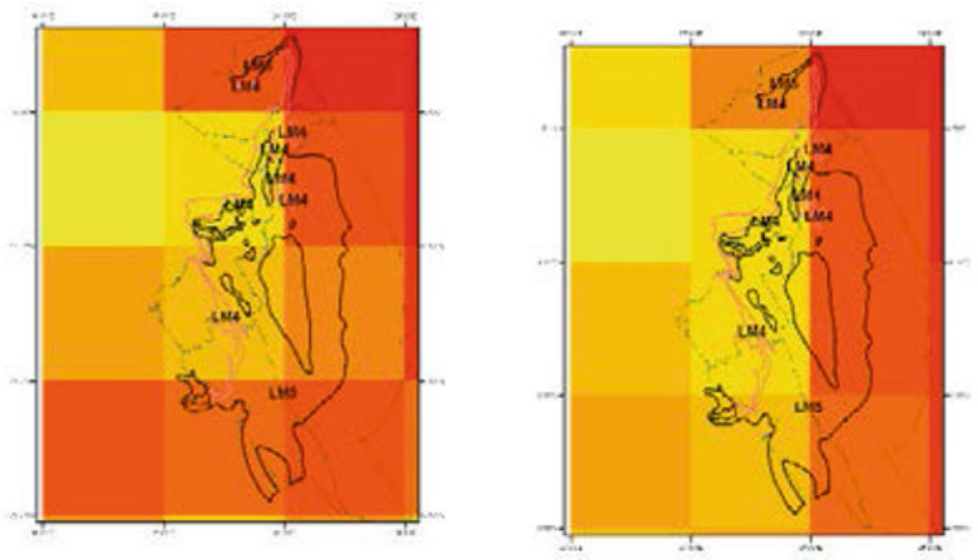

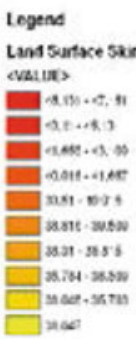

Surface Skistrisomialure variabon in ligroezclogical zone IV and V Time Average Mas: 2002 2018 at spatid resclution of 1 dagee A.RSTTMONO
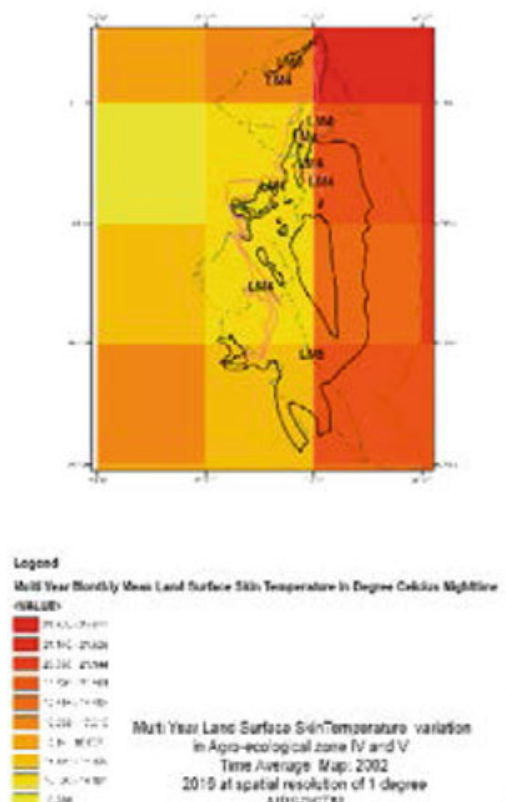

\section{Legend}

Land surface Skin Ttmperatare in Degree Cekchas Night tme svatue>

एasacas

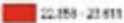

Dinvi-22es

Datenth

- ats?-nie

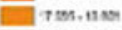

D.625-17se4

D $201 \mathrm{6sa}$

Tom-15.65

Solace ShinTernseratus volation in Agmo reoingieal zane N and V Time Average Mag 2002

2016 at ipoial iesclution of 1 depree MRSSTMVCo
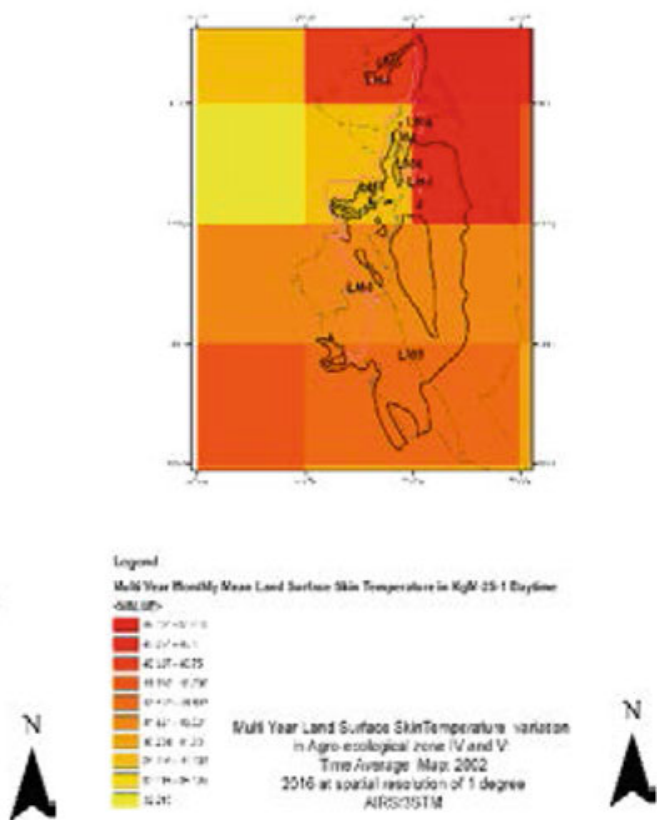

Fig. 3 Land surface skin temperature variations in agro-ecological lower midland zone IV and V 
sea level are likely to be regions that will experience the highest changes in suitability for crops.

Additionally, this chapter made effort to deeply make observations on monthly Land surface skin temperatures for the period 2002-2016 at $1^{\circ}$ spatial resolution to further improve on understanding of the analysis. Figure 3 shows significant variations within the agro-ecological lower midland zones IV and V. Such variability in land surface temperatures in any area is a manifestation of variation of vegetation responses to water stress (Sun 2009; Pinheiro et al. 2006). Land surface temperature has been confirmed to be a very important parameter for environmental as well as climate studies (Pinheiro et al. 2006). It is also important to note that currently, weather stations provide limited data on spatial patterns of temperatures over large areas as shown by Assiri (2017). This leaves interpretation of the land surface temperatures from satellite imagery a viable option. It would, therefore, be prudent to argue that land surface temperature is a key parameter in understanding crop water stress within any agro-ecological zone.

The significance of land surface temperatures in climate monitoring cannot be ruled out in the extreme weather event scenarios as reported by Sun (2009). Furthermore, Vlassova et al. (2014) emphasize land surface temperature as an important parameter in soil-vegetation transfer modeling in most terrestrial environments. This parameter becomes even more important in evaluating cropping seasons and assessment of length of growing periods in such areas. Time average maps of multi-year monthly daytime and nighttime land surface temperatures for the period 2002-2016 are also presented for agro-ecological zones IV and V (Fig. 3). Evidently, there are significant variations across the entire agro-ecological lower midlands zones IV and $\mathrm{V}$ area as also confirmed by the monthly daytime and nighttime temperatures for the same period. Assiri (2017) demonstrated high correlation between moderate resolution imaging spectroradiometer (MODIS) satellite nighttime land surface temperature which also had high correlation with station-based minimum temperatures as compared to the daytime land surface temperatures. The accuracy and effectiveness of MODIS land surface temperature was further corroborated by those of Kenawy et al. (2019). Apparently, Sun (2009) showed that land surface temperature uses/values to be quite wide and included but not limited to hazard prediction, water management in agriculture, crop management, in terms of crop stress monitoring and yield forecasting and nonrenewable resource management. In addition, the authors provide contribution to work done regarding assimilation of land surface temperatures in soil moisture monitoring through the surface energy balance assimilation scheme.

This chapter also makes observations on soil temperatures for $0-10 \mathrm{~cm}, 10$ $40 \mathrm{~cm}$, and $40-100 \mathrm{~cm}$ for the period $1998-2014$ at a spatial resolution of $0.25^{\circ}$ since the focus of understanding agro-ecological zones currently suitable for certain crops and the cropping seasons. These products do not seem to show significant differences among the various soil depths (Fig. 4). This could probably be attributed to vegetation cover, an important element in thermal conditions of soils (Holmes et al. 2008). This condition has the ability to influence the vertical differentiation of soil temperatures as previously revealed by Skawina et al. (1999). What was striking is 

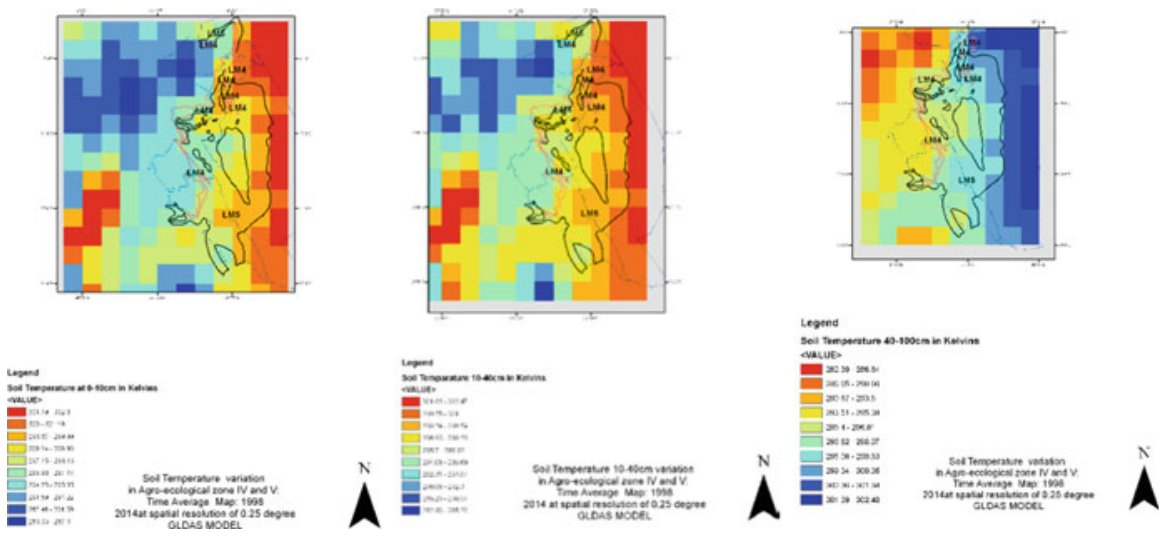

Fig. 4 Soil temperature variations in agro-ecological lower midland zone IV and V
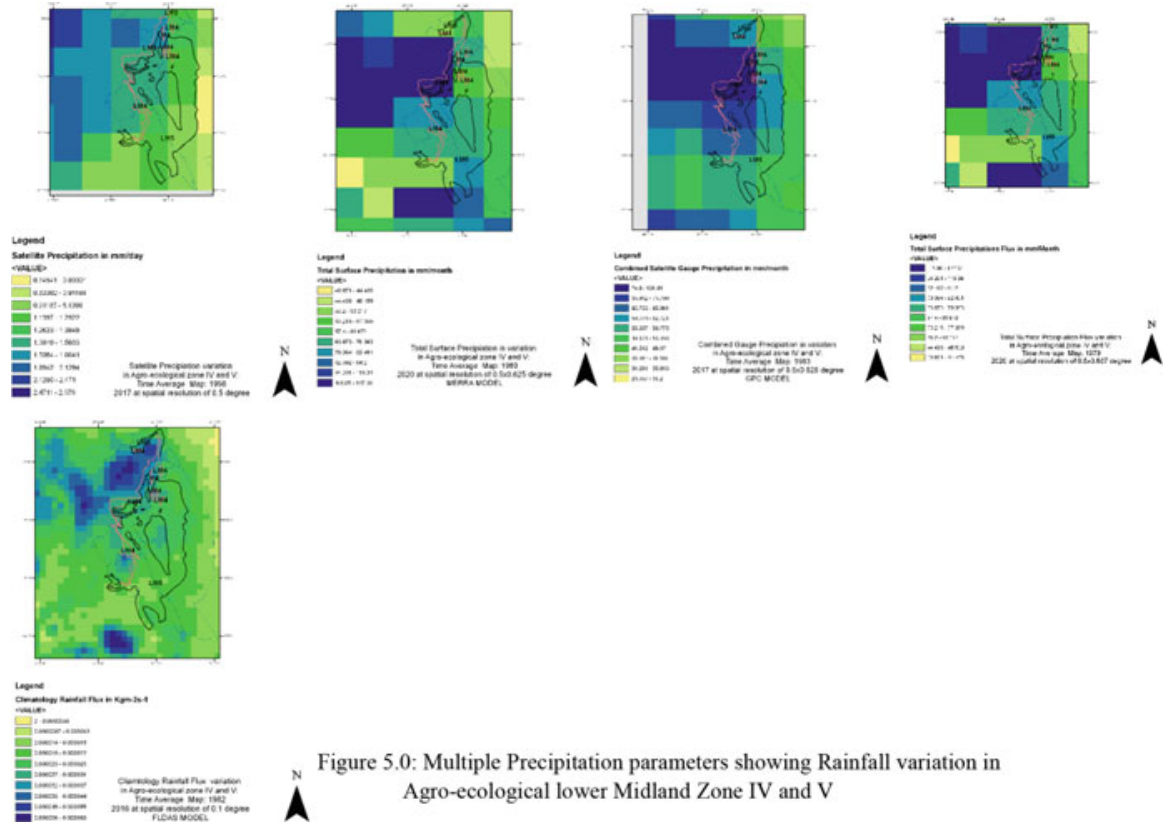

Figure 5.0: Multiple Precipitation parameters showing Rainfall variation in
Agro-ecological lower Midland Zone IV and V

Fig. 5 Multiple precipitation parameters showing rainfall variation in agro-ecological lower midland zone IV and V

the significant variation identified within the agro-ecological lower midland zones IV and V with the soil temperatures varying across Makueni, Machakos, Tharaka Nithi all the way to the small parts of Meru, i.e., the ranges are 26.85-22.85, 20.85$24.85,24.85-26.85$, and 17.85-23.85, respectively, for all areas (see Fig. 5). These observations summarize quite significant and clear changes that have been taking 
place within the zones over a long period as result of climate variability and extreme weather events. Similar observations have been reported before by Buckman and Brady (1971) who stressed the significance of soil in agriculture since it is the medium upon which crops are grown. They confirm that significant chemical and biological reactions begin when certain temperatures are optimal in the soil media. Moreover, Skawina et al. (1999) demonstrated the significance of weather conditions on the thermal properties of soil. This, therefore, means that significant climate variability influence soil temperatures positively or negatively and thereby affecting crop growth.

Soil temperature parameters therefore become extremely important factors to consider in agro-ecological zone characterization as shown by studies of OsińskaSkotak (2007) who reported that soil temperatures were influenced by meteorological situations taking place. Onwuka (2018) confirms that soil temperatures are affected by environmental factors especially by controlling the heat on the soil surface and heat dissipated from the soil down the profile. The importance of soil temperature cannot be overemphasized in this chapter. Indeed Sabri et al. (2018) showed that biological processes such as seed germination, seedling emergence, plant root growth, and the availability of key nutrients are components dependent on soil temperature, moreso the transmission of water inside the plant. In addition, injuries in the plant tissue at root zone can occur as a result of fluctuation in temperatures (lower or higher) as attested by Decker (1955). This could imply that soil temperatures fluctuation could the reason for high soil-borne diseases due to injury of plant tissues. It could also be the explanation for high soil-borne disease incidences associated with climate change. Schollaert Uz et al. (2019) documents the role that remote sensing datasets can play in linking different climatic variability events to pest and disease incidences. In this chapter, the coupling of crop models to pest and diseases model together with climates are considered as new frontiers to enabling monitoring of pests and diseases outbreaks under extreme weather events for early preventative measures.

\section{Precipitation Amount, Rate, and Soil Moisture Variations}

Several earth observation products modeled for precipitation analysis were used in this chapter for understanding variations within the agro-ecological lower midland zones IV and V as shown in Fig. 5. The first product we considered was the average time maps for precipitation monthly for the period 1998-2017 (recorded in mm/day) at spatial resolution of $0.5^{\circ}$. This revealed variations in precipitation amounts within these areas. The amounts varied across the areas in consideration with Kitui and Makueni showing a range between 1.39 and $0.9 \mathrm{~mm}$ /day, while Machakaos had precipitation amounting to $1.59-1.89 \mathrm{~mm} /$ day and Tharaka Nithi and Meru exhibiting 1.39-1.89 mm/day and 1.26-1.59 mm/day, respectively. Another product of interest that observed was the total monthly surface precipitation in $\mathrm{mm} /$ day for a spatial resolution $0.5 \times 0.625^{\circ}$ for the period $1980-2020$. This product also showed significant variation within the agro-ecological lower midland zones IV and V where 
places like Makueni and Kitui showed precipitation amounts of $63.67-44.43 \mathrm{~mm} /$ month with small pockets showing higher precipitation amounts of 70.36$82.49 \mathrm{~mm} / \mathrm{month}$. Machakos area had rainfall ranges between 70.36 and $94.2 \mathrm{~mm} /$ month with some small areas to the North East experiencing precipitation amounts of 94.2-118.04 mm/month. Finally, Tharaka Nithi and parts of the drier Meru experienced precipitation amounts of 70.36-118.04 and 53.4-48.2 $\mathrm{mm} / \mathrm{month}$, respectively. The combined satellite gauge precipitation monthly in $\mathrm{mm} / \mathrm{month}$ at spatial resolution of $0.5^{\circ}$ for the period 1983-2017 also formed an interesting observation set. There were clear and interesting variations on precipitation amounts within the agro-ecological lower midland zones IV and V. This product specifically showed 49.17-62.72 mm/month for Makueni and Kitui, while for Machakos the precipitation ranges between 69.96 and $101.61 \mathrm{~mm} /$ month. Tharaka Nithi and Meru show precipitation amount of $59.77-101.61 \mathrm{~mm} / \mathrm{month}$ with a small area to the northeast showing $41.51-49.17 \mathrm{~mm} / \mathrm{month}$. Finally, the time average maps of climatology of rainfall flux monthly for the period 1982-2016 at spatial resolution of $0.1^{\circ}$ in $\mathrm{Kg} / \mathrm{m}^{-2} / \mathrm{s}^{-1}$ was also observed. The observation pointed to the fact that substantial variations existed within the area of the agro-ecological lower midland zones IV and V. All products showed a significant rise in precipitation amount for areas, especially Makueni, Kitui, and Machakos. We observe that these areas have experienced gradual increase in rainfall amounts in some pockets, e.g., Machakos as compared to earlier reports by Jiitzold and Kutsch (2000), implying a rising trend. On the contrary, Makueni and Kitui areas seem to register a downward trend in precipitation (see Fig. 5 and Table 1). Over the years, these semi-arid regions have been described to be regions of limited precipitation (Slatyer and Mabbutt 1964). However, Managua (2011) had conflicting views, indicating a rise in rainfall for the period 2020-2050 for most parts of Kenya. These scenarios of high unprecedented rainfall are currently being experienced in Kenya.

Precipitations in the marginal areas have been described to undergone considerable positive change, indicating trends of increasing rainfall amounts in some pockets. Other studies have reported conflicting (negative trends), indicating the failure to include the changing Indian Ocean weather patterns; - something that may affect climate data modeling along semi-arid regions as argued by Herrero et al. (2010). Vrieling et al. (2013) gave a comprehensive descriptive dataset on changes in weather patterns which showed an increasing trend in the dry period between the short and long rains and this has been happening at the expense of short rains. Interestingly, Elbasit et al. (2014) has also demonstrated that there is a good agreement between satellite Tropical Rainfall Measuring Mission (TRMM) 3B43 products and the monthly rain gauge information, confirming increasing trend in rainfall and the reliability on Tropical Rainfall Measuring Mission (TRMM) earth observation products for climate monitoring.

The variations observed and scenarios of higher precipitations in some part of the agro-ecological lower midlands zones IV and V call for future evaluation of the cropping season as well as the length of growth periods. The proper and reliable estimation of onset and cessation of precipitation is critical in rain-fed agriculture in the semi-arid areas as emphasized by Fiwa (2014). Incidentally, existing information 
shows that the relationship between precipitation onset, cessation, and length of growing period becomes very important in the planning of agricultural activities especially among smallholder farmers in Africa (Fiwa et al. 2014). In this chapter, therefore, we are of the opinion that there is an upward increase in precipitation in these marginal areas and but the absolute increase the precipitations have vast variability. Aming et al. (2014) also identified precipitation extremes and higher variabilities in arid and semi-arid parts of Africa, the findings which seem to be in line with our observations in these agro-ecological lower midland zones IV and V of Kenya. Fluctuation and variations in the rainfall have also been confirmed by Camberlin (2009) with indications showing serious variations from one weather station to another, especially in the long rains of East Africa. The growing developments in satellite-based rainfall assessments provide a cheaper alternative to rainfall data that is available for free online (Kumar and Reshmidevi 2013). The collection of rainfall data using passive or active remote sensing techniques has a potential to bring a more informed way of handling climate change in Africa and moreso Kenya with huge landmass represented by arid and semi-arid regions. These methods of rainfall data collection can be described as brightness temperature for passive method (Hengl et al. 2010) and attenuation of the radar power at several heights to estimate surface rain for the active method (Skolnik 1962; Meneghini et al. 1983; Hengl et al. 2010).

Rainfall intensity from earth observation data is known to show variations within the agro-ecological lower midland zones IV and V (Fig. 6). Higher precipitation rates are associated with areas of high precipitation as shown in Fig. 6. High precipitation rate is associated with runoff and hence low soil moisture content (Mutiga et al. 2013). This further affects the length of growing period and expected cropping seasons. Notably, high runoff is associated with low productivity of soil and causes severe risk in agriculture as result of climate hazard (Gatot et al. 2001). Furthermore, it is known that soils experiencing high runoff as result of high rainfall intensity are normally very low infertility due to the percolation of soil nutrients. Rainfall intensity monitoring in agro-ecological zone of marginal areas of Kenya is key since high level of runoff in the semi-arid areas are highly associated with precipitation rates as well as poor farming practices. Fiwa et al. (2014) asserts that rainfall intensity monitoring using weather satiation is a real challenge across Africa. Thies (2008) evaluated rainfall intensity data from satellite imagery differentiation techniques and concludes that they offer potential for improved rainfall rate. This allows for spatiotemporal near real-time information on rainfall distribution. This kind of data and techniques in Africa will definitely address the challenges facing climatesmart crop management under extreme weather events whenever they will be fully available.

Additional products considered included soil moisture content below the ground at $0-10 \mathrm{~cm}, 10-40 \mathrm{~cm}$, and $40-100 \mathrm{~cm}$, soil temperatures at $0-10 \mathrm{~cm}, 10-40 \mathrm{~cm}$, and $40-100 \mathrm{~cm}$, see (Fig. 7). These additional products provide information on moisture availability for the various crops within the agro-ecological lower midland zones IV 
Fig. 6 Daily precipitation rate variation in agroecological lower midland zone IV and V

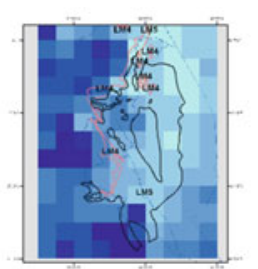

Legend

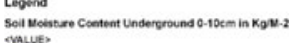

watues

-

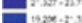

-

-

thesering

- $150 x-152 n$

Dan-ues

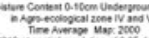

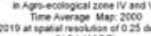
oct wotet.

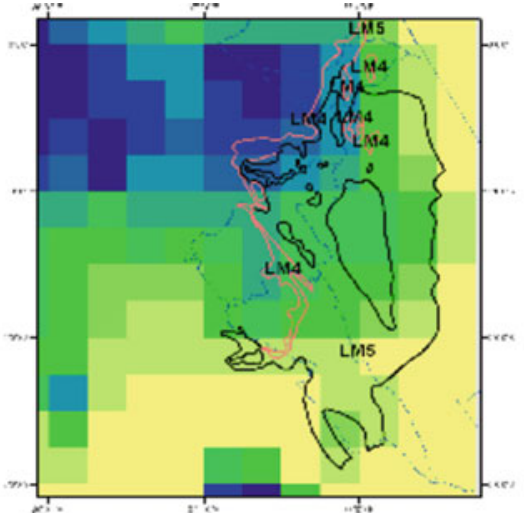

Legend

Precipitation Rate in mm/day

¿VALUE>

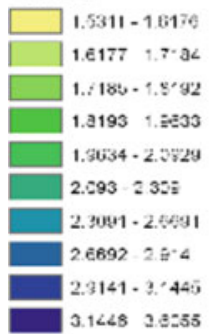

Precipiation Rate variation in Agrc-ecological zone IV and V: Time Average Map: 1998 2019 at spatial resolution of 0.25 degree

Fig. 7 Soil moisture content underground variations in agro-ecological lower midland zones IV and $\mathrm{V}$
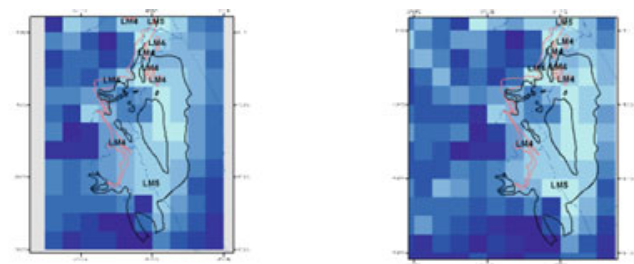

Legend

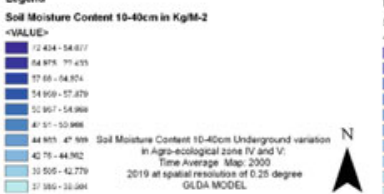

Legend

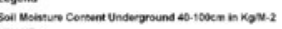

vatue

Uastims

=

-

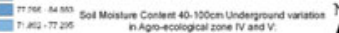

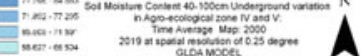


and V. This chapter makes a contribution on knowledge on increased variability in soil moisture content across the entire study area. This can be attributed to the verse variance in soil types and soil characterizes as well as canopy cover. This can also be related to the various changes in climatic;- soil related weather parameters. Other factors affecting soil moisture contents are human-induced activities that cause land degradation (FAO 2002). Degraded soils have very low water retention capacity hence low soil moisture content. The role that soil moisture content plays in crop development cannot be overemphasized. Every crop requires good soil moisture content to stimulate activities between the shoot and the root zone. Soil moisture contents are identified as key factor determining length of growth period which impact on cropping seasons and crop suitability in any agro-ecological zones.

Kamara and Jackson (1997) states that soil moisture is a better indicator of water availability to the crop than rainfall amount. Improved soil moisture management can only take place when analysis of soil moisture content are carried out and are well understood. Understanding soil moisture content scenarios assist in working toward high water retentions in the soil which eventual reduction in soil runoff in some cases. In semi-arid regions, the issue of soil moisture becomes very important since moisture stress in crop is one of the key determinants of crop failure. In other studies, Pellarin et al. (2020) has shown that soil moisture content can be used to infer precipitation using PrISM Model. This kind of modeling is said to provide useful information concerning crop yield estimates and irrigation demands over large areas. In his research, comparison made with weather station information showed that there was high correlation proving the significance and the role that soil moisture content below ground plays in understanding shifting precipitation patterns. Overall soil moisture content is vital in understanding cropping season, i.e., low soil moisture levels are indications of declining length of growing period for crops. The biggest challenge identified by this chapter is existence of many soil moisture algorithms and products that cannot be compared to other parameters such as precipitation as propounded by Pellarin et al. (2020). He further indicated the need for analysis that can integrate other parameters such as precipitation for the proper validation of satellite soil moisture and also system that can determine the relationship between different soil moisture products.

\section{Evapotranspiration Variations}

The other parameter that this chapter observed is evapotranspiration. The monthly evapotranspiration earth observation reported here are for the period 1998-2014 at spatial resolution of $1^{\circ}$ and recorded in $\mathrm{Kgm}^{-2} \mathrm{~s}^{-1}$ (see Fig. 8). The values indicated a variation in evapotranspiration across the agro-ecological lower midland zones IV and $\mathrm{V}$ area. There were no products for comparison with previous periods in order to understand any changes in evapotranspiration. Areas like Meru agro-ecological lower midland zones IV and V revealed higher evapotranspiration rates. This could be explained by high vegetation cover known to be in this region and high soil moisture content. Evapotranspiration is directly related to soil moisture content and 
Fig. 8 Evapotranspiration variation in agro-ecological lower midland zone IV and V
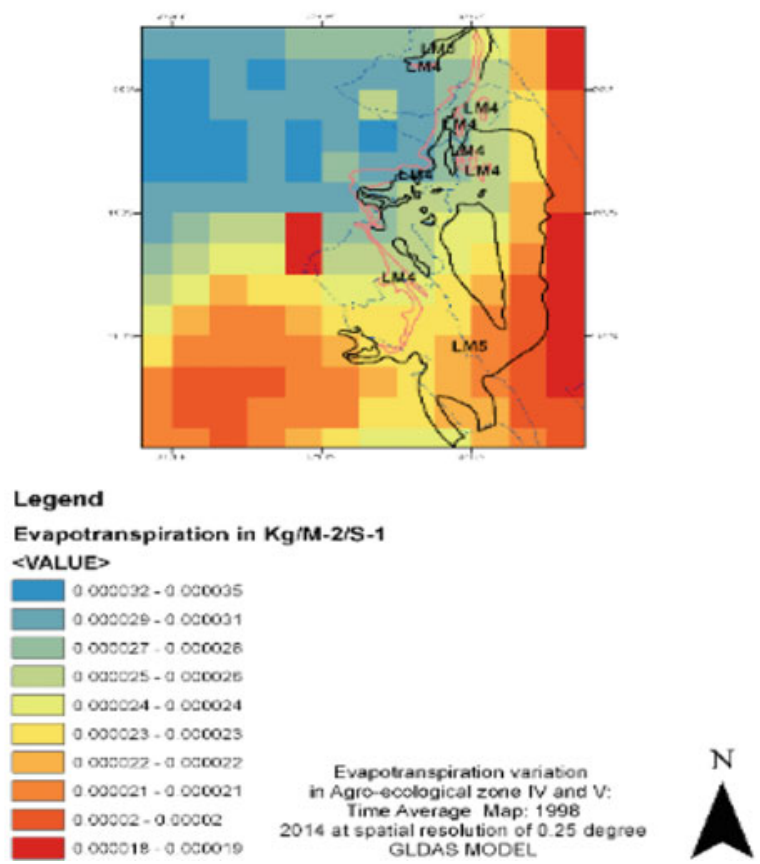

atmospheric moisture demand (Fischer et al. 2008). Further Fisher et al. (2008) shows that soil moisture is as a result of precipitation while atmospheric moisture emanates from radiation that is controlled by surface and atmospheric temperatures.

Areas in Kitui and Makueni experience very low Evapotranspiration, which could also be due to low vegetation covers that are characteristic of these areas. These indicate that areas of high evapotranspiration rates are likely to have longer growing period. Table 1 classifies these areas and reveal that they have similar short cropping season as those with very low evapotranspiration rates. Evapotranspiration as shown by studies of Jiitzold and Kutsch (2000) shows variations in the length of growing periods which eventually determine the cropping seasons. In this case, the evapotranspiration employed statistical methods of Penman \& McCulloch with albedo for green grass being 0.2; McCulloch (1965). This is not to imply its inadequacy but rather the need for improvement. Liou and Kar (2014) confirms that evapotranspiration at a global or regional scale can be done by combining surface parameters obtained from remote sensing data and surface meteorological variable and vegetation characteristics. Marshall and Funk (2014) describes evapotranspiration as an important component in the energy, water, and geochemical cycles that influence climate properties and further says that its interaction with drivers of climate change remain unexplored in Africa.

A combination of a number of parameters and variables in a climate change scenario is likely to improve evapotranspiration analysis and interpretation. This 
would further improve on the assessments of cropping seasons. Marshall and Funk (2014) in his discussion points out the usefulness of satellite imagery in representing important characteristics of evapotranspiration over Africa. Similar results have been reported by Dai (2010) who showed rising temperatures in Africa and a decreasing evapotranspiration as result of low precipitation and low soil moisture content. Satellite imagery products through available remote sensing techniques can enhance the availability of spatial and temporal datasets of Normalized Difference Vegetation Index (NDVI), Leaf Area Index (LAI), fraction of incidence sunlight that reflects, surface radiations, and radiometric surface temperatures that are indirectly related to evapotranspiration (Liou and Kar 2014). Further Henricksen (1986) present extensive report on the length of growing period model that was used that seem to work well in drought simulations in Africa. He pointed out the inability of the model to analyze moisture level below 1 month and the assumption of the model concerning runoff and deep percolation.

\section{Contribution of GIS and Remote Sensing in Agro-ecological Zone Evaluations}

The suitability of gridded climate indices in monitoring climatic variation is demonstrated in Donat et al. (2013) studies. The gridded climatic indices can enable near real-time monitoring of events as well as their placement for long-term use at both global and regional scales. Boitt et al. (2014) in his studies on the impact of climate change on agro-ecological zones and this chapter has made quite a number of inferences from their work regarding GIS and remote sensing. There are siginificant shifts in agro-ecological zones based on datasets analyzed and projections for future in 2050. These shifts and changes can be picked at apporoximately $1 \mathrm{~km}$ and significantly identified as "zone shift." Boitt et al. (2014) further concluded that multivariate clustering under a GIS enviroment is a very informative tool for agroecological zone definition. Global agro-ecological zone module V is the latest model for defining crop suitability for various regions. This module utilizes various climate datasets such as number of rainy days; mean minimum, mean maximum temperature; diurnal temperature range; cloudiness; wind speed and vapor pressure (IIASA/ FAO 2012). Among this climate dataset, soil parameters are accommodated extensively (IIASA/FAO 2012). Its use among African countries is still limited and therefore needs to be scaled for adoption to the benefit of smallholder farmer levels. Its adoption is generally challenged by the limited use of GIS and remote sensing datasets in most African countries (Rowland et al. 2007). This module could provide the new insights into understanding climate variability and its impact on cropping seasons. Its use in evaluating existing information on agro-ecological zones of lower midland IV and $\mathrm{V}$ is paramount.

Wango et al. (2018) explore the suitability of WorldClim dataset in climate analysis and monitoring in the advent of climate change. All previous studies highlighted the role of GIS and remote in transforming the understanding of climate variability, thereby successfully addressing the climate change issues in Kenya and 
Africa at large. For example, Henricksen (1986) emphasize the use of satellite remote sensing to capture and monitor the climate variability occurring year after year. Another research by Bartoszek et al. (2015), for Poland, affirms the use of satellite data as useful source of temporal and spatial variability of information on climate. FAO (2017) in the report on review of remote sensing tools, products, and methodologies points out, the issues that Africa is facing, when it comes to improved crop production forecasting. The reports highlights the improvement in technologies related to remote sensing and the mode of communication which are at varying levels of development. Further, the reports mention the problems of various institutions, especially the government, to integrate and use effectively remote sensing products. This in the end has affected timely crop forecasting across the continent. Finally, there are readily available good products of early warning system that Africa should take advantage of since they are free.

\section{Climate-Smart Crop Management}

According to Mungai (2017), smallholder farmers in the East African region are facing unprecedented challenges in pursuit of increased production under increased climate change and variability. His work further gives highlights on the dire need for information on possible risk and viable management strategies. Information on risk stem from understanding the climate variability within the agro-ecological zones where farming is defined as discussed in previous sections of this chapter. Nsubuga and Rautenbach (2018) concluded that climate variability is bound to have considerable effects in terms of food availability, especially on the agriculture depended populations. They further point out that climatic variations and differences will continue to have a significant role in the geographic distribution of crop production. Understanding climate variations within agro-ecological zones and their influence on the soil environment is key in climate-smart crop management. The parameters selected in this chapter present time average maps that have shown increasing variations over years as result of climate change. Scaling down satellite imagery and remote sensing technologies for use by smallholder farmer presents one possible solution for the reduction of the impact of climate variability on food security. Previous studies have presented the challenges therein while highlighting various solutions that can be adopted. Nsubuga and Rautenbach (2018) in their reviews highlighted the importance of rainfall measurements in Uganda but failed to show a downward trend in rainfall amount yet there has been as shift precipitation rates as well as end and start of seasons. We looked at some of the climate-smart crop management practices that have been suggested and implemented. The chapter underpins the importance of climatic variability evaluation at agro-ecological zone level scaled down to farmers needs for successful climate-smart crop management. Food and Agriculture Organization (FAO) focus on climate-smart crop production pushes for crop production and practices that enable climate change and mitigation. In this view, different methods have been recommended and used. One of the approaches that has been advocated for is cropping systems which are believed to 
cushion farmers against climate change shocks. The other is the use of quality seeds and plantings adapted to the various environments. Sustainability and the resilience of a production system is believed to be achieved through improved crop varieties suited for a wide range of agro-ecosystem FAO (2013).

Changes in temperature, precipitation, assessment of evapotranspiration characteristics and soil temperature-moisture regimes necessitate for new frontiers in the management of crops through introduction of adoptable technologies. Report by FAO (2013) on climate-smart crop production pushes for agricultural systems that are very efficient in terms of inputs while at the same having less variability. This will enable sustainability through the stability in the outputs hence more resilient in nature and therefore able to cushion against climate change shock and long-term variability. On the other hand, climate-smart intervention by smallholder farmers cannot be ignored (Ullah et al. 2019). Even though most of the local coping strategies and mechanism may be weak as earlier mentioned, they can be strengthened by incorporating them in technology-based smart inventions.

Another adaptation for climate-smart agriculture is through crop modeling that focuses on building early warning monitoring systems that effectively alter the overall management of the crop in volatile climate environment (Ullah et al. 2019). In his studies, he highlights the use of weather data smart interventions that involve close monitoring of climate variability and relaying of information to relevant stakeholders. This is bound to improve further if implemented under an environment of well evaluated and monitored agro-ecological zoning. This means, the cropping seasons and length of growing period variations within agro-ecological zones will be factored in. The advent of weather data smart intervention and yield forecasting through crop modeling place the use of satellite imagery in products provision in crucial place. Weather data smart intervention cannot forget platforms of forecasting more frequently to the farmers. Stigter (2010) gave focus on the importance of such advisory services in his studies. Zuma-Netshiukhwi et al. (2016) in his study emphasizes on the need for agro-meteorological knowledge transfer or extension services to end-users such as farmers and other relevant stakeholders. Further, he discusses the need for downscaling of seasonal climate to lower resolutions that can address the farmers' needs. Abura (2017) argues that there is need for meteorological department to streamline climate advisory services to the locals so that livelihoods risk as result of climate change can be reduced. This can be done by training of agricultural extension officer who in most developing countries work hand in hand with the smallholder farmers.

\section{Conclusion}

This chapter concludes that variation within agro-ecological lower midland zones IV and $\mathrm{V}$ does exist and changes have been occurring over a long period of time. All the products from GIOVANNI NASA Earth data website have shown enormous variations. Secondly, earth observation products used alongside in situ information have the potential of improving agro-ecological zoning and the interpretation of the 
cropping season and crop suitability. Thirdly, climate studies that have relayed conclusive information on agro-ecological zones have focused more on rainfall with exclusion of more datasets that can provide more insight in terms of understanding climatic trends and cropping systems.

Fourthly, use of more varied datasets that focus on varied precipitation parameters, varied temperatures parameters, evapotranspiration, thermal conditions of soil, and soil moistures content are likely to improve on the understanding of length of growing period, hence enabling the adoptions of crop varieties that are climate-smart for particular regions. The low adoption of earth observation products and technologies in remote sensing poses a problem in the monitoring of climate variability in Africa. Effective assessment of length of growing periods from climate information for Africa need to be strengthened and improved through adoption of earth observation products alongside in situ surveillance. Finally, the climate-smart crop management must be considered to cut across the various sectors and not agriculture alone if successful implementation is to be achieved. Agricultural systems can achieve climate-smart objectives through continuous monitoring of activities being undertaken at the agro-ecological zones level since they form very important platforms of crop productions in Kenya. This study confirms that climate-smart crop management under extreme weather in Kenya is unavoidable. This management will stem from the adoptions of technologies, strategies, and policies that focus on climate monitoring, evaluation of exiting agro-ecological zones, and adoption of agro-ecosystems that can support sustainable agriculture. In addition, future studies on climate change impact on marginal areas should consider focusing on further reclassification of agro-ecological zones in Kenya and evaluation of cropping season using both satellite imagery and in situ information to compensate for challenges and gaps experienced in previous studies. This will assist smallholders' farmers in addressing the current challenges that they have as a result of climate variability. Soil moisture assessment and integration and its inter-comparison to other parameters still remain a challenge that needs to be addressed.

\section{References}

Abura BA, Hayombe PO, Tonui WK (2017) Rainfall and temperature variations overtime (19862015) in Siaya county, Kenya. Int J Educ Res 5:11-20

Aming P, Awange JL, Forootan E, Ogallo A, Girmaw B, Fesseha I, Kululetera V, Mbati M, Kilavi M, King M, Adek P, Njogu A, Badr M, Musa A, Muchiri P (2014) Changes in temperature and precipitation extremes over the Greater Horn of Africa region from 1961 to 2010. 1277(June 2013): 1262-1277. https://doi.org/10.1002/joc.3763

Assiri ME (2017) Assessing MODIS land surface temperature (LST) over Jeddah. Polish J Environ Stud 26:1461-1470. https://doi.org/10.15244/pjoes/68960

Ayugi BO, Tan G (2019) Recent trends of surface air temperatures over Kenya from 1971 to 2010. Meteorol Atmos Phys 131:1401-1413. https://doi.org/10.1007/s00703-018-0644-Z

Bartoszek K, Siłuch M, Bednarczyk P (2015) Characteristics of the onset of the growing season in Poland based on the application of remotely sensed data in the context of weather conditions and land cover types. Eur J Remote Sens 48:327-344 
De Beurs KM, Henebry GM (2010) Spatio-temporal statistical methods for modeling land surface phenology. In: Hudson IL, Keatley MR (eds) Phenological research: methods for environmental and climate change analysis. Springer, Dordrecht, pp 177-208

Boitt MK, Mundia CN, Pellikka P (2014) Modelling the impacts of climate change on agroecological zones-a case study of Taita Hills, Kenya. Univers J Geosci 2:172-179. https://doi. org/10.13189/ujg.2014.020602

Buckman HC, Brady NC (1971) Soil and its properties (in polish). PWRiL Press, Warsaw

Camberlin P, Moron V, Okoola R et al (2009) Components of rainy seasons' variability in equatorial East Africa: onset, cessation, rainfall frequency and intensity. Theor Appl Climatol 98:237-249. https://doi.org/10.1007/s00704-009-0113-1

Dai A (2010) Drought under global warming. Interdiscip Rev Clim Change 3(6):617-617. https:// doi.org/10.1002/wcc. 81

Decker WL (1955) Determination of soil temperatures from meteorological data. Retrospect Teses Dissert 13252. https://lib.dr.iastate.edu/rtd/13252

Donat MG, Alexander LV, Yang H et al (2013) Global land-based datasets for monitoring climatic extremes. Bull Am Meteorol Soc 94:997-1006. https://doi.org/10.1175/BAMS-D-12-00109.1

Eitzinger A, Laderach P, Quiroga A, et al (2011) Future climate scenarios for Kenya's tea growing areas. pp $1-27$

Elbasit MA, Adam EO, Khalid Abu-Talib1, Ahmed F, Yasuda H, Ojha CSP (2014) Validation of satellite-based rainfall measurements in arid and semi-arid regions of sudan. Proc 10th Int Conf AARSE

FAO (1978) Agro-ecological zoning, guidelines, Food and Agricultural Organization of the United Nations, Rome

FAO (1996) Agro-ecological zoning, guidelines. Food and Agricultural Organization of the United Nations, Rome

FAO (2002) Conservation agriculture - optimizing soil moisture for palnt production; the significance of soil porosity. In FAO Soils Bulletin No. 79. FAO, Rome. ISBN 92-5$1046255.69 \mathrm{p}$

FAO (Food and Agriculture Organization) (2013) Climate smart agriculture source book main report E-ISBN 978-92-5-107721-4 (PDF). https://www.fao.org/climatechange/climatesmart Climate-Smart@fao.org

FAO (Food and Agriculture Organization) (2017) Review of the available Remote sensing tools, products, methodologies and data to improve crop production forecasts, Rome 2017, https:// www.fao.org/publications. ISBN 978-92-5-109840-0

Fischer G, Shah M, Van H, Nachtergaele F (2006) Agro-ecological zones assessment

Fischer G, Nachtergaele F, Prieler S, Velthuizen HT, van Verelst L, Wiberg D (2008) Global Agroecological zones: model documentation. Food Agri Organ UN

Fiwa L, Vanuytrecht E, Wiyo KA, Raes D (2014) Effect of rainfall variability on the length of the crop growing period over the past three decades in central Malawi. Clim Res 62:45-58. https:// doi.org/10.3354/cr01263

Gatot IS, Duchesne J, Forest F, et al (2001) Rainfall-runoff harvesting for controlling erosion and sustaining upland agriculture development. pp 431-439

Gregory PJ, Ingram JSI, Brklacich M (2005) Climate change and food security. Philos Trans R Soc B Biol Sci 360(1463):2139-2148. https://doi.org/10.1098/rstb.2005.1745

Guo HD, Zhang L, Zhu LW (2015) Earth observation big data for climate change research. Adv Clim Chang Res 6:108-117. https://doi.org/10.1016/j.accre.2015.09.007

Hastenrath S (2001) Variations of east African climate during the past two centuries. Clim Chang 50:209-217. https://doi.org/10.1023/A:1010678111442

Hengl T, AghaKouchak A, Tadic MP (2010) Methods and data sources for spatial prediction of rainfall. In Testik FY, Gebremichael M (eds) Rain-fall: state of the science. American Geophysical Union (AGU), pp 186-214 New Age International Publisher.

Henricksen BJ (1986) Determination of agro-ecological zones in Africa: ILCA activities and expectations. ILCA Bull 23:15-22 
Herrero M, Ringler C, Steeg J, Van De, Koo J, Notenbaert A (2010) Climate variability and climate change and their impacts on Kenya's agricultural sector. ILRI, Nairobi, Kenya 1-56. https://doi. org/10.5539/jsd.v6n2p9

Holmes TRH, Owe M, De Jeu RAM, Kooi H (2008) Estimating the soil temperature profile from a single depth observation: a simple empirical heat flow solution. Water Resour Res 44:1-11. https://doi.org/10.1029/2007WR005994

IIASA/FAO, 2012. Global agro-ecological zones (GAEZ v3.0). IIASA/FAO, Laxenburg/Rome

Jiitzold R, Kutsch H (2000) Agro-ecological zones of the tropics, with a sample from Kenya. April 1982

Kamara SI, Jackson IJ (1997) A new soil-moisture based classification of raindays and dry days and its application to Sierra Leone. Theor Appl Climatol 56(3-4):199-213. https://doi.org/10.1007/ BF00866427

Kenawy AM, Hereher ME, Robaa SM (2019) An assessment of the accuracy of MODIS land surface temperature over Egypt using ground-based measurements. Remote Sens 11. https://doi. org/10.3390/rs 11202369

King'uyu SM, Ogallo LA, Anyamba EK (2000) Recent trends of minimum and maximum surface temperatures over eastern Africa. J Clim 13:2876-2886. https://doi.org/10.1175/1520-0442 (2000)013<2876:RTOMAM $>2.0$. CO;2

Kumar DK, Reshmidevi TV (2013) Remote sensing applications in water resources. J Indian Inst Sci 93(2):163-187

Le Page Y, Vasconcelos M, Palminha A, Melo IQ, Pereira JMC (2017) An operational approach to high resolution agro-ecological zoning in West-Africa. PLo SONE 12(9): e0183737. https://doi. org/10.1371/journal.pone.0183737

Liou YA, Kar SK (2014) Evapotranspiration estimation with remote sensing and various surface energy balance algorithms-a review. Energies 7(5):2821-2849. https://doi.org/10.3390/ en7052821

Managua C (2011) Future climate scenarios for Uganda Tea growing areas. Managa, CIAT

Marshall M, Funk C (2014) Examining evapotranspiration trends in Africa Examining evapotranspiration trends in Africa. https://doi.org/10.1007/s00382-012-1299-y

McCulloch JSG (1965) Tables for the rapid computation of the Penman estimate of evaporation. E Afr Agric J 30:286

Mendelsohn R (2008) The impact of climate change on agriculture in developing countries. J Nat Resour Policy Res 1:5-19. https://doi.org/10.1080/19390450802495882

Meneghini R, Eckerman J, Atlas D (1983) Determination of rain rate from a spaceborne radar using measurements of total attenuation. IEEE Trans Geosci Remote Sens 1:34-43

Mungai C (2017) Adoption and dissemination pathways for climate-smart agriculture technologies and practices for climate-resilient livelihoods in lushoto, Northeast Tanzania. Climate 5:63. https://doi.org/10.3390/cli5030063

Mutiga JK, Su Z, Woldai T (2013) Corrigendum to "using satellite remote sensing to assess evapotranspiration: case study of the upper Ewaso Ng'iro North Basin, Kenya". Int J Appl Earth Obs Geoinf 23(1):411. https://doi.org/10.1016/j.jag.2012.10.011

Ndirangu S, Mbogoh S, Mbatia O (2017) Effects of land fragmentation on food security in three agro-ecological zones of embu county in Kenya. Asian J Agri Ext Econ Soc 18(4):1-9. https:// doi.org/10.9734/ajaees/2017/34321

Nsubuga FW, Rautenbach H (2018) Climate change and variability: a review of what is known and ought to be known for Uganda. Int J Clim Chang Strateg Manag 10(5):752-771. https://doi.org/ 10.1108/IJCCSM-04-2017-0090

Nsubuga FWN, Botai OJ, Olwoch JM, Rautenbach CJd W, Bevis Y, Adetunji AO (2014) La nature des précipitations dans les principaux sous-bassins de l'Ouganda. Hydrolog Sci J 59(2):278299. https://doi.org/10.1080/02626667.2013.804188

Ochieng J, Kirimi L, Mathenge M (2015). Effects of climate variability and change on agricultural production: the case of small scale farmers in Kenya. NJAS Wagen J Life Sci 77:71-78. https:// doi.org/10.1016/j.njas.2016.03.005. (2016) 
Omondi PA o, Awange JL, Forootan E et al (2014) Changes in temperature and precipitation extremes over the Greater Horn of Africa region from 1961 to 2010. Int J Climatol 34:12621277. https://doi.org/10.1002/joc.3763

Osińska-Skotak K (2007) Studies of soil temperature on the basis of satellite data. Int Agrophys 21 (3):275-284

Onwuka B (2018) Effects of soil temperature on some soil properties and plant growth. Adv Plants Agric Res 8:34-37. https://doi.org/10.15406/apar.2018.08.00288

Parry M, Rosenzweig C, Iglesias A et al (1994) Climate change and world food security: a new assessment. Glob Environ Chang 9. https://doi.org/10.1016/S0959-3780(99)00018-7

Pearce D (2000) Policy frameworks for the ancillary benefits of climate change. Assess Ancillary Benefits Costs Greenh Gas Mitig 517-560

Pellarin T, Román-Cascón C, Baron C et al (2020) The precipitation inferred from soil moisture (PrISM) near real-time rainfall product: evaluation and comparison. Remote Sens 12:481. https://doi.org/10.3390/rs12030481

Pinheiro ACT, Privette JL, Guillevic P (2006) Modeling the observed angular anisotropy of land surface temperature in a savanna. IEEE Trans Geosci Remote Sens 44:1036-1047

Rowland J, Wood E, Tieszen LL, Lance K, Khamala E, Siwela B, Adoum A, Brown M (2007) Review of remote sensing needs and applications in Africa prepared by : contributors : development 1-124. https://doi.org/10.13140/RG.2.1.1101.3849

Sabri NSA, Zakaria Z, Mohamad SE, Jaafar AB, Hara H (2018) Importance of soil temperature for the growth of temperate crops under a tropical climate and functional role of soil microbial diversity. Microb Environ 33(2):144-150. https://doi.org/10.1264/jsme2.ME17181

Schneider U, Becker A, Ziese M, Rudolf B (2018) Global precipitation analysis products of the GPCC. Glob Precipitation Climatology Cent 1-14

Schollaert Uz S, Ruane AC, Duncan BN et al (2019) Earth observations and integrative models in support of food and water security. Remote Sens Earth Syst Sci 2:18-38. https://doi.org/ 10.1007/s41976-019-0008-6

Schreck CJ, Semazzi FHM (2004) Variability of the recent climate of eastern Africa. Int J Climatol 24(6):681-701. https://doi.org/10.1002/joc.1019

Seo SN, Mendelsohn R, Dinar A et al (2009) A Ricardian analysis of the distribution of climate change impacts on agriculture across agro-ecological zones in Africa. Environ Resour Econ 43:313-332. https://doi.org/10.1007/s10640-009-9270-z

Skawina T, Kossowski J, Stêpniewski W, Walczak R (1999) Physical properties of soils (in polish). In: Zawadzki S (ed) Soil science. PWRiL Press, Warsaw

Skolnik MI (1962) Introduction to radar. Radar Handbook, 2

Slatyer RO, Mabbutt JA (1964) Hydrology of arid and semiarid regions. Section 24 V.T

Stigter K, Walker S, Das HP, Huda S, Dawei Z, Jing L, Chunqiang L, Hurtado IHD, Mohammed AE, Abdalla AT, Bakheit NI, Al-Amin NKN, Yurong W, Kinama JM, Nanja D, Haasbroek PD (2010) Meeting farmers' needs for agrometeorological services: an overview and case studies

Sun Y (2009) Retrieval and application of land surface temperature. Geo-UtexasEdu 1:1-27

Thies B, Nauß T, Bendix J (2008) Precipitation process and rainfall intensity differentiation using meteosat second generation spinning enhanced visible and infrared imager data. J Geophys Res Atmosp 113:1-19. https://doi.org/10.1029/2008JD010464

Ullah W, Wang G, Ali G et al (2019) Comparing multiple precipitation products against in-situ observations over different climate regions of Pakistan. Remote Sens 11:628. https://doi.org/ $10.3390 /$ rs 11060628

Vlassova L, Perez-Cabello F, Nieto H et al (2014) Assessment of methods for land surface temperature retrieval from landsat-5 TM images applicable to multi-scale tree-grass ecosystem modeling. Remote Sens 6:4345-4368. https://doi.org/10.3390/rs6054345

Vrieling A, De Leeuw J, Said MY (2013) Length of growing period over Africa: variability and trends from 30 years of NDVI time series. Remote Sens 5:982-1000. https://doi.org/10.3390/ rs5020982

Wango TJL, Musiega D, Mundia CN (2018) Assessing the suitability of the worldclim dataset for ecological studies in Southern Kenya. J Geogr Inform Syst 10(06):643-658. https://doi.org/ 10.4236/jgis.2018.106033 
White MA, de Beurs KM, Didan K, Inouye DW, Richardson AD, Jensen OP, O'Keefe J, Zhang G, Nemani RR, van Leeuwen WJD et al (2009) Intercomparison, interpretation, and assessment of spring phenology in North America estimated from remote sensing for 1982-2006. Glob Chang Biol 15:2335-2359

Zuma-Netshiukhwi GN, Stigter KC, Walker S (2016) Improving agricultural decision making using weather and climate information for farmers, south-western Free State, South Africa. Net J Agric Sci 4:67-77

Open Access This chapter is licensed under the terms of the Creative Commons Attribution 4.0 International License (http://creativecommons.org/licenses/by/4.0/), which permits use, sharing, adaptation, distribution and reproduction in any medium or format, as long as you give appropriate credit to the original author(s) and the source, provide a link to the Creative Commons license and indicate if changes were made.

The images or other third party material in this chapter are included in the chapter's Creative Commons license, unless indicated otherwise in a credit line to the material. If material is not included in the chapter's Creative Commons license and your intended use is not permitted by statutory regulation or exceeds the permitted use, you will need to obtain permission directly from the copyright holder.

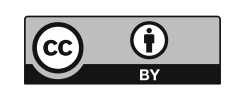

